\title{
EFEKTIVITAS PENINGKATAN MOTIVASI ENTREPRENEURIAL MELALUI PEMBELAJARAN ENTREPRENEURSHIP
}

\author{
Arisman Telaumbanua \\ IKIP Gunungsitoli \\ arismant9@gmail.com \\ M. Giatman \\ Universitas Negeri Padang \\ giat5131@yahoo.co.id \\ Ernawati Nazar \\ Universitas Negeri Padang \\ Ernawatiunp44@gmail.com
}

\section{Suggested Citation:}

Rakib, Muhammad. 2010. The Effect of Entrepreneurial Communication Model, Entrepreneurial Learning, and Entrepreneurship Attitudes on Small Business Performance. Jurnal IImu Pendidikan,17(2): 121-129

\section{Abstrak:}

Tujuan penelitian ini ialah untuk mengungkap dan melihat pengaruh pembelajaran entrepreneurship terhadap motivasi Entrepreneurial. Jenis penelitian ini adalah penelitian asosiatif kausal, dimana sampel dalam penelitian ini adalah siswa kelas XI Teknik keahlian bisnis konstruksi dan properti yang berjumlah 68 orang. Instrumen penelitian ini menggunakan angket yaitu angket pembelajaran entrepreneurship dan angket motivasi Entrepreneurial. Teknik analisis regresi digunakan untuk proses analisis data penelitian. ini Hasil penelitian ini secara umum disimpulkan bahwa terdapat hubungan fungsional linear positif yang searah pengaruh antara pembelajaran entrepreneurship dan motivasi Entrepreneurial. Besarnya korelasi pembelajaran entrepreneurship dengan motivasi entrepreneurial adalah 0,847.

Kata Kunci: Motivasi Entrepreneurial, Pembelajaran Entrepreneurship

\section{Abstract:}

This research purpose is to reveal and see the effect of learning entrepreneurship on Entrepreneurial motivation. This type of research is causal associative research, where the sample in this research is class XI student of construction and property business expertise totaling 68 people. This research instrument uses a questionnaire, namely entrepreneurship learning questionnaire and entrepreneurship motivation questionnaire. Multiple regression analysis techniques are used to analyze research data. The results of this study are generally concluded that there is a positive linear functional relationship that is in the same direction as the relationship between entrepreneurship learning and Entrepreneurial motivation. The magnitude of the correlation of entrepreneurship learning with entrepreneurial motivation is 0.847 .

Keywords: Entrepreneurship learning, Entrepreneurial motivation 


\section{Pendahuluan}

Masalah kemiskinan dan pengangguran menjadi masalah utama dalam ekonomi, apalagi di negara Indonesia dan negara berkembang lainnya. Pengangguran diartikan sebagai orang yang mampu dan bersedia bekerja namun belum menemukan mata pencaharian tetap. Orang-orang yang menganggur ini bertolak ke kota berharap mendapatkan pekerjaan di kota, namun mayoritas dari mereka tidak memperoleh pekerjaan dikarenakan kurangnya keahlian dan pengalaman mereka (Azlina, dkk, 2017). Masalah baru yang diciptakan oleh tingkat pengangguran, terutama yang berhubungan dengan ketersediaan perumahan, kesehatan dan sanitasi, kejahatan dan kriminal lainnya.

Jika pertumbuhan ekonomi adalah salah satu efek dari implikasi teknologi, maka mesti ada seseorang atau sekelompok orang yang bertindak untuk mengaplikasikan sesuatu untuk kegiatan produktif seperti kombinasi baru dari sumber produksi (Muda, 2017). Kegiatan ini memperlihatkan inovasi yang dilaksanakan oleh pengusaha. Wirausahawan dengan berbagai inovasinya dapat disimpulkan bahwa wirausaha akan bisa menghasilkan barang atau jasa, membuka lapangan pekerjaan, meningkatkan penghasilan, sehingga akhirnya keadaan ini akan meningkatkan ketentraman masyarakat dan menjadikan keseluruhan kegiatan ekonomi jadi lebih baik. Pertumbuhan ekonomi diharapkan mampu diciptakan malaui kontribusi SMK.. Khususnya melalui sektor informal.

Sekolah Menengah Kejuruan (SMK) idalah pendidikan formal yang mempunyai pola pelatihan khusus untuk membimbing siswa agar ikut berperan aktif di dunia usaha atau bisnis dan secara profesional, menjadi lulusan yang siap bekerja. Tantangan pendidikan kejuruan adalah menyiapkan mutu Sumber Daya Manusia (SDM) sesuai dengan kebutuhan di berbagai sektor, terlebih sektor industri dan jasa. Terjadi persaingan yang ketat di semua bidang kehidupan saat ini di era globalisasi dengan terjadinya peningkatan permintaan akan SDM di pasar tenaga kerja. Untuk mempersiapkan lulusan SMK yang memenuhi kualifikasi pasar kejuruan, perlu untuk meningkatkan kualitas dan kemampuan lulusan sekolah kejuruan.

Siswa adalah agen perubahan yang dapat berguna dalam pemberdayaan masyarakat yang sulit untuk dicapai. Siswa harus memiliki motivasi yang kuat terhadap keinginan untuk memasuki dunia bisnis. Motivasi entrepreneurial terlihat dari ketekunan dan kemauan untuk bekerja keras untuk kemajuan bisnisnya, kemudian kemauan menerima jenis risiko yang terkait dengan tindakan, mau menempuh jalan baru dan baru, kemauan untuk hidup hemat, kemauan untuk hidup hemat belajar dari pengalaman. (Munawar, 2015). Menurut Uno dalam Winarsih (2014), indikator motivasi entrepreneurial adalah sebagai berikut (1) ada keinginan dan hasrat berhasil; (2) ada cita-cita dan harapan masa depan; (3) ada penghargaan dalam entrepreneurial; (4) ada dorongan dalam berwirausaha; (5) ada kegiatan yang menarik dalam entrepreneurial.

Proses pembelajaran di sekolah utamanya bertujuan buat memberi bekal anak didik dalam membuatkan karakter, kemampuan akademik, serta dasar kecakapan yang kuat melalui pembelajaran program adaptif, produktif dan normative. Munir, dkk (2015) melalui tulisannya mengatakan bahwa keberhasilan wirausaha tergantung pada faktor lingkungan seperti faktor ekonomi, hukum, sosial, politik dan teknologi yang mempengaruhi faktor motivasi sehingga mengarah pada kewirausahaan yang sukses. Motivasi adalah faktor kunci yang mempengaruhi perilaku kewirausahaan dan operasi bisnis.

Entrepreneur adalah pilihan karir yang layak, memuaskan, bermanfaat dan dihargai bagi lulusan. Sebagai pengakuan atas kontribusi besar pengusaha, mereka kadang-kadang secara sehari-hari disebut sebagai 'penggerak' di tengah masyarakat. Jika entrepreneur dianggap sebagai sumber inovasi, membuka peluang lapangan kerja, dan kemajuan ekonomi suatu negara, maka sangat penting untuk menarik kaum muda dan orang-orang terpelajar untuk menjadi entrepreneurs. Pembelajaran entrepreneurship ini dimaknai sebagai proses pentransferan ilmu entrepreneurship kepada anak didik dengan tujuan untuk membangkitkan motivasi entrepreneur serta melahirkan entrepreneur baru. Mengacu pada anggapan Suherman dalam Rakib (2010) bahwa indikator-indikator entrepreneurship learning yang akan dijelaskan adalah sebagai berikut: (1) Kemampuan guru yang dapat menumbuhkan motivasi entrepreneurial. (2) Memotivasi untuk berwirausaha dengan materi pembelajaran entrepreneurship yang sesuai. (3) Pengalaman langsung yang dapat 
menumbuhkan motivasi entrepreneurial.(4) Menumbuhkan motivasi entrepreneurial melalui variasi metode pembelajaran.

Pembelajaran entrepreneurship dapat membentuk pola pikir, sikap, motivasi dan perilaku seseorang menjadi seorang wirausahawan (entrepreneur). Berdasarkan latar belakang yang telah diuraikan, peneliti tertarik untuk melakukan penelitian terkait hal tersebut. Tujuan penelitian ini ialah untuk mengungkap dan melihat pengaruh pembelajaran entrepreneurship terhadap motivasi entrepreneurial.

\section{Metode Penelitian}

Penelitian kuantitatif dengan analisis regresi digunakan pada penelitian ini. Penelitian ini memiliki variabel independen yakni pembelajaran entrepreneurship $(X)$, dan variabel dependen yakni motivasi entrepreneurial $(Y)$. Sampel penelitian ini ialah siswa kelas XI Teknik keahlian bisnis konstruksi dan properti yang berjumlah 68 orang. Instrumen penelitian ini menggunakan angket yaitu angket pembelajaran kewirausahan dan angket motivasi entrepreneurial siswa. Alat pengukur yang digunakan adalah skala bertingkat dengan 4 alternatif jawaban dimana masing-masing terdiri dari 20 butir pernyataan.

\section{Hasil Penelitian}

Dilakukan uji Linieritas hubungan pembelajaran entrepreneurship dengan motivasi entrepreneurial terlebih dahulu sebelum dilakukan uji analisis regresi. Hasil uji linieritas dapat dilihat pada tabel berikut ini:

Tabel 1

ANOVA Table

\begin{tabular}{|c|c|c|c|c|c|c|c|c|}
\hline & & & & Sum of Squares & $\mathrm{df}$ & Mean Square & $\mathrm{F}$ & Sig. \\
\hline \multirow{5}{*}{$\begin{array}{l}\text { Pembelajaran } \\
\text { Kewirausahaan* } \\
\text { Motivasi } \\
\text { Berwirausaha }\end{array}$} & \multirow{3}{*}{$\begin{array}{l}\text { Between } \\
\text { Groups }\end{array}$} & (Combined) & & 47.200 & 5 & 9.440 & 19.571 & .000 \\
\hline & & Linearity & & 45.645 & 1 & 45.645 & 94.629 & .000 \\
\hline & & $\begin{array}{l}\text { Deviation } \\
\text { Linearity }\end{array}$ & from & 1.555 & 4 & .389 & .806 & .530 \\
\hline & \multicolumn{2}{|c|}{ Within Groups } & & 16.400 & 63 & .482 & & \\
\hline & \multicolumn{2}{|l|}{ Total } & & 63.600 & 68 & & & \\
\hline
\end{tabular}

Sumber : Data diolah (2020)

Tabel di atas ialah hasil uji linieritas dilihat pada nilai sig deviasi linieritasnya $(0,530)>0,05$. berarti Ho diterima, berarti terdapat hubungan linieritas antara pembelajaran entrepreneurship dan motivasi entrepreneurial. Selanjutnya, hasil Output SPSS uji regresi linier sederhana seperti terlihat pada tabel berikut:

Tabel 2

Coefficients $^{\mathrm{a}}$

\begin{tabular}{|c|c|c|c|c|c|c|c|c|}
\hline \multirow[b]{2}{*}{ Model } & & \multicolumn{2}{|c|}{$\begin{array}{l}\text { Unstandardized } \\
\text { Coefficients }\end{array}$} & $\begin{array}{l}\text { Standardized } \\
\text { Coefficients }\end{array}$ & \multirow[b]{2}{*}{$\mathrm{t}$} & \multirow[b]{2}{*}{ Sig. } & \multicolumn{2}{|c|}{$\begin{array}{l}95,0 \% \text { Confidence } \\
\text { Interval for B }\end{array}$} \\
\hline & & B & $\begin{array}{l}\text { Std. } \\
\text { Error }\end{array}$ & Beta & & & $\begin{array}{l}\text { Lower } \\
\text { Bound }\end{array}$ & $\begin{array}{l}\text { Upper } \\
\text { Bound }\end{array}$ \\
\hline 1 & (Constant) & 3.658 & .347 & & 10.532 & .000 & 2.955 & 4.361 \\
\hline & $\begin{array}{l}\text { Pembelajaran } \\
\text { Entrepreneurhip }\end{array}$ & 1.021 & .104 & .847 & 9.829 & & .811 & 1.231 \\
\hline
\end{tabular}

a. Dependent Variable: Motivasi Entrepreneurial

Sumber : Data diolah (2020) 
Dari tabel diperoleh nilai $\mathrm{Sig}=0,00<0,05$ artinya $\mathrm{H}_{0}$ ditolak, Ini berarti bahwa variable pembelajaran entrepreneurship berpengaruh secara signifikan terhadap motivasi entrepreneurial. Persamaan Regresi yang diperoleh: $Y=3,658+1,021 X$.

Tabel 3

Model Summary

\begin{tabular}{lrrrrr}
\hline Model & $\mathrm{R}$ & R Square & Adjusted R Square & Std. Error of the Estimate \\
\hline 1 & & $.847^{\mathrm{a}}$ & .718 & .710 & .687
\end{tabular}

a. Predictors: (Constant), Pembelajaran Kewirausahaan

Sumber : Data diolah (2020)

Dari table model summary digunakan untk melihat nilai korelasi $(R)$. disimpulkan bahwa korelasi pembelajaran entrepreneurship $(X)$ dengan motivasi Entrepreneurial $(y)$ adalah 0,847 . Nilai ini didefenisikan bahwa hubungan antara pembelajaran entrepreneurship dan motivasi entrepreneurial dikategorikan kuat atau erat. Pada tabel summary ini juga terlihat nilai koef. determinan (KD atau $R$ Square) yang memperlihatkan seberapa baik model regresi yang terbentuk, sebagai hasil interaksi variabel independen dan variabel dependen. Diperoleh nilai $\mathrm{KD}=71,8 \%$ yang dapat didefenisikaan bahwa variabel bebas $\mathrm{X}$ mempunyai pengaruh sumbangan sebesar $71,8 \%$ terhadap variabel $Y$ dan dipengaruhi oleh faktor-faktor lain sebesar $28,2 \%$ diluar variabel atau bervariasinya motivasi Entrepreneurial dapat dijelaskan sebesar $71,8 \%$ oleh bervariasinya pembelajaran entrepreneurship.

\section{Pembahasan}

Berdasarkan tabulasi data responden didapatkan bahwa responden lebih banyak menyatakan setuju pada penyataan "metode pembelajaran entrepreneurship sangat menarik sehingga dapat menumbuhkan motivasi terhadap kewirausahaan". Pengaruh pembelajaran entrepreneurship sebesar $71,8 \%$. Dari persamaan tersebut juga dapat diartikan bahwa setiap peningkatan pembelajaran entrepreneurship sebesar 1 , maka akan meningkatkan (karena nilainya positif) motivasi entrepreneurial sebesar 1,021\%. Hasil penelitian dengan analisis deskriptif menunjukkan bahwa secara umum Pembelajaran entrepreneurship telah dilaksanakan dengan kategori tinggi. Hal ini menunjukkan guru sudah menerapkan pembelajaran aktif, inovatif, kreatif, efektif, dan menyenangkan. Untuk dapat meningkatkan pembentukan motivasi entrepreneurial. Secara keseluruhan hasil penelitian menunjukkan bahwa pengaruh pembelajaran entrepreneurship bisa meningkatkan motivasi entrepreneurial. Dengan demikian bahwa terdapat pengaruh yang positif dan signifikan pembelajaran entrepreneurship terhadap motivasi entrepreneurial siswa SMK Negeri 1 Hiliserangkai. Semakin tinggi pembelajaran entrepreneurship dilaksanakan, maka akan semakin tinggi motivasi entrepreneurial siswa. Sebaliknya semakin rendah pembelajaran entrepreneurship, maka akan semakin rendah pula motivasi entrepreneurial siswa.

Hasil ini menunjukkan bahwa motivasi entrepreneurial siswa dipengaruhi oleh pengalaman pribadi siswa. Pengalaman pribadi yakni pengalaman belajar tentang kewirasusahaan. Pengalaman belajar yang mendalam tidak ditunjukkan oleh lamanya belajar, tetapi intensitas interaksi dalam belajar, dan terjadi transfer belajar dalam diri siswa (Stoltz, 2008). Interaksi belajar kewirausahaan di sekolah, tidak hanya hubungan antara guru dan siswa, tetapi terjadinya interaksi antara siswa dengan materi pelajaran entrepreneurship dan pelajaran itu bermakna bagi siswa. Suatu pelajaran akan bermakna apabila dalam proses belajarnya dapat melibatkan emosi siswa. Adanya interaksi mendalam antara siswa dengan pelajaran kewirausahaan diharapkan akan membentuk motivasi positif siswa terhadap entrepreneurship. Faktor lain yang berperan dalam pembentukan motivasi entrepreneurialialah guru, karena guru merupakan salah satu sumber pengaruh perubahan motivasi ke arah positif.

Pembelajaran Entrepreneurship adalah bagian dari pembelajaran seumur hidup (Sezen-Gultekin \& Gurerdogan, 2016) dan ini adalah fenomena yang dapat diamati, proses yang dilakukan oleh para pengusaha dan 
dianggap penting karena merupakan konsep yang telah diberikan penilaian tinggi dalam literatur akademik dalam dekade terakhir (Sezen Gultekin \& Gur-Erdogan, 2016; Ernest, et al., 2015, Toktarova \& Mamatov, 2015). Temuan-temuan penelitian ini telah mengarah pada pengidentifikasian komponen-komponen utama yang terkait dengan pembelajaran Entrepreneurship. wirausaha telah dianggap sebagai prosedur psikologis yang terjadi dengan beragam niat individu. berbagai tingkat persepsi dan faktor-faktor yang bertanggung jawab untuk stimulus (Hussain, 2015; Solesvik, 2013). Selanjutnya, telah diakui bahwa motif tunggal memiliki kemampuan untuk membuat seseorang menjadi wirausahawan yang efektif dan niat dapat timbul karena faktor internal dan eksternal (Shane, Locke \& Collins, 2003).

Studi empiris telah membuktikan bahwa kurangnya sikap dan sumber daya yang sesuai dari siswa yang menjalankan perusahaan di ekonomi transisi dapat menghambat kemajuan perusahaan yang menunjukkan hubungan vital antara motivasi Entrepreneurship dan pembelajaran Entrepreneurship (Solesvik, 2013). Telah diakui bahwa universitas berada dalam posisi untuk meningkatkan pembelajaran Entrepreneurship dengan mengembangkan motivasi dan kompetensi lulusan untuk menjadi kepribadian terkemuka dalam proses inovatif dan Entrepreneurship (Rasmussen \& Sorheim, 2006).

Pembelajaran Entrepreneurship di sekolah, tidak hanya interaksi antara siswa dan guru, namun siswa berinteraksi juga dengan materi pelajaran entrepreneurship dan terjadi pembelajaran secara bermakna dalam proses belajar siswa yang melibatkan emosinya. Diharapkan dengan adanya interaksi antara siswa dan pelajaran Entrepreneurship dapat siswa termotivasi secara positif terhadap Entrepreneurship itu sendiri. Guru juga berperan aktif dalam memotivasi siswa dalam Entrepreneurial dikarenakan guru. Hal ini senada dengan Suryana (2013), pengusaha sukses pada dasarnya ialah mereka yang mempunyai kompetensi, yaikni memiliki keahlian, kualitas serta pengetahuan sendiri yang berupa nilai-nilai pribadi, perilaku, dan motivasi yang diperlukan dalam bertindak dan bekerja. Menurut Kristanto (2009) basic Entrepreneurship Education dari sumber Entrepreneurship yang terkandung dalam diri individu. Pengusaha tidaklah akan berhasil bila tidak mempunyai kemauan, pengetahuan, dan keahlian. Pendidikan entrepreneurship tidak didapatkan dari pendidikan formal saja, melainkan banyak faktor di luar faktor pendidikan yang juga dapat meningkatkan pengetahuan Entrepreneurship. Penelitian ini didukung oleh penelitian sebelumnya oleh Yunal and Indriyani (2013), disimpulkan bahwa pendidikan entrepreneurship mempunyai pengaruh positif dan signifikan terhadap motivasi entrepreneurial.

\section{Kesimpulan}

Berdasarkan hasil pembahasan serta analisis disimpulkan bahwa pembelajaran Entrepreneurship telah dilaksanakan dan dikategorikan sangat tinggi, demikian pula motivasi Entrepreneurial siswa SMK Negeri 1 Hiliserangkai dikategorikan sangat tinggi. Hasil penelitian ini secara umum disimpulkan bahwa terdapat hubungan fungsional linear positif yang searah hubungan antara pembelajaran Entrepreneurship dan motivasi Entrepreneurial. Hal tersebut berimplikasi bahwa dalam memprediksi pembentukan motivasi Entrepreneurial siswa SMK Negeri 1 Hiliserangkai haruslah memperhitungkan besaran dari variabelnya.

\section{Referensi}

Azlina, N., Hasan, A., Desmiyawati \& Muda, I. (2017). The Effectiveness of Village Fund Management (Case Study at Villages in Coastal Areas in Riau). International Journal of Economic Research, 14(12): 325-336.

Ernest, K., Matthew, S. K., and Samuel, A. K., (2015). Towards Entrepreneurial Learning Competencies: The Perspective of Built Environment Students. Higher Education Studies, 5(1): 20-30.

Hussain, A. (2015). Impact of Entrepreneurial Education on Entrepreneurial Intentions of Pakistani

Students. Entrepreneurship and Business Innovation, 2(1), 43-53.

Kristanto, R. Heru. (2009). Entrepreneurship: Management Decisions and Practices. Yogyakarta: Graha llmu. 
Muda, Iskandar, (2017). The Effect of Supervisory Board Cross-Membership and Supervisory Board Members' Expertise to The Disclosure of Supervisory Board's Report: Empirical Evidence From Indonesia. European Research Studies Journal, XX(3A). 702-716.

Munawar., Rosmiati \& Donny. T.S.J. (2015). Sikap, Motivasi dan Minat Entrepreneurial Mahasiswa. Jurnal Manajemen dan Kewirausahaan, 17(1): 21-30.

Munir, Z ., Idrus, S ., Shukur, S\& Ithnin, R \& Mohamad, S. (2015). The Effectiveness of Entrepreneurial Motivational Training Programme among University Students. International Journal of Social Science and Humanity, 5. 487-490. 10.7763/IJSSH.2015.V5.505.

Rasmussen, E. \& Sorheim, R. (2006). Pendidikan kewirausahaan berbasis tindakan. Technovation, 26(2): 185194

Stoltz, Paul Gordon. (2008). Adversity Quotient (Mengubah Hambatan Menjadi Peluang). Terjemahan oleh Hermaya. Jakarta: Grasindo.

Sezen Gultekin, G. and Gur Erdogan, D., (2016). The Relationship and Effect between Lifelong Learning Tendencies and Social Entrepreneurship Characteristics of Prospective Teachers. Anthropologist, 24(1):113118.

Shane, S., Locke, E. A. and Collins, C. J. (2003). Entrepreneurial Motivation. Human Resource Management Review, 13(2): 257-279.

Solesvik, M. Z. (2013). Entrepreneurial motivation and intentions: investigating the role of education major. Education \& Training, 55(3): 253-271.

Suryana, Yuyus. (2019). Entrepreneurship. Jakarta: Kencana.

Toktarova, V. and Mamatov, D. (2015). Implementation of the adaptive learning model based on learning styles. Theory \& Practice of Social Development, 8(1): 231-236.

Winarsih, P. (2014). Minat Entrepreneurial ditinjau dari Motivasi serta Sikap Kewirausahaan pada Mahasiswa Program Studi Pendidikan Akuntansi. Jurnal Publikasi. hlm 1-13.

Yunal, O. V and Indriyani, R, (2013). Analysis of the Influence of Entrepreneurship Motivation and Product Innovation on Grass Crafts Business Development in West Lombok. Petra Christian University Journal, 1(1): 111. 